\title{
Temperature and methane changes over the past 1000 years recorded in Dasuopu glacier (central Himalaya) ice core
}

\author{
YAO Tandong, ${ }^{1}$ DUAN Keqin,,${ }^{1}$ XU Baiqing,,${ }^{1}$ WANG Ninglian,,${ }^{1}$ PU Jianchen,,${ }^{1}$ KANG Shighang, ${ }^{1}$ \\ QIN XIANG, ${ }^{1}$ Lonnie G. THOMPSON ${ }^{2}$ \\ ${ }^{1}$ Cold and Arid Regions Environmental and Engineering Research Institute, Chinese Academy of Sciences, Lanzhou, Gansu 730000, China \\ E-mail:tdyao@ns.lzb.ac.cn \\ ${ }^{2}$ Byrd Polar Research Center, The Ohio State University, 108 Scott Hall, 1090 Carmack Road, Columbus, OH 43210-1002, U.S.A.
}

\begin{abstract}
In 1997, three ice cores were recovered from Dasuopu glacier on the northern slope of the central Himalaya. The first core, $159.9 \mathrm{~m}$ long, was drilled at $7000 \mathrm{~m}$ a.s.l. down the flowline from the top of the col. The second core, $149.2 \mathrm{~m}$ long, was drilled on the $\mathrm{col}$ at $7200 \mathrm{~m}$ a.s.l. The third core, $167.7 \mathrm{~m}$ long, was also drilled on the col at $7200 \mathrm{~m}$ a.s.l., $100 \mathrm{~m}$ away from the second core. The present paper discusses the $\delta^{18} \mathrm{O}$ and methane results reconstructed for the past 1000 years based on the second core. The $\delta^{18} \mathrm{O}$ can be interpreted as an air-temperature signal. The methane concentration is mainly representative of atmospheric methane concentration. Both $\delta^{18} \mathrm{O}$ and methane records show an obvious increasing trend in the past 1000 years. Methane concentration in the record is similar to the fluctuations of $\delta^{18} \mathrm{O}$, decreasing during cold periods and increasing during warm periods. The Little Ice Age was well recorded in the core by both $\delta^{18} \mathrm{O}$ and methane. The coldest period appeared in the late 18 th century, accompanied by a decrease in methane concentration. The abrupt methane-concentration increase starting after the 18th century is no doubt due to anthropogenic input. The observed methane-concentration decrease during World Wars I and II clearly demonstrates the importance of the anthropogenic input to atmospheric methane concentration if further measurements prove that it is a true atmospheric signal.
\end{abstract}

\section{INTRODUGTION}

It was recently pointed out (Jones and others, 2001) that the 20 th century is the warmest period of the last millennium. Many scientists think that the increased concentration of greenhouse gases in the atmosphere explains the dramatic global warming (Rasmussen and Khalil, 1984; Blunier and others, 1993). Ice-core methane reconstructions are believed to reflect atmospheric methane-concentration fluctuations with time (Chappellaz and others, 1987, 1990, 1993b; Stauffer and others, 1988; Blunier and others, 1993, 1995) and to reveal the past changes in terrestrial methane emissions (Chappellaz and others, 1993a). The most recent and longest Vostok (Antarctica) ice-core reconstruction (Petit and others, 1999) indicates that the main trends of methane concentration are similar over the last four climatic cycles (last 420000 years), with the maximum during interglacials $(650-770 \mathrm{ppbv})$ and the minimum during glacial periods $(320-350 \mathrm{ppbv})$. The Vostok study also reveals that the present-day level of methane (1700 ppbv) is unprecedented during the past $420 \mathrm{kyr}$.

Several ice cores have been recovered from mountains in the subtropical latitudes, such as the Dunde (Thompson and others, 1989; Yao, 1997) and Guliya ice cores (Thompson and others, 1997; Yao and others, 1999a, b) from the Tibetan Plateau, the Quelccaya (Thompson and others, 1985) and Huascarán ice cores (Thompson and others, 1995) from the Andes, and the Sajama ice core from Bolivia (Thompson and others, 1998). Temperature, precipitation patterns and atmospheric composition of soluble and insoluble species for different periods were reconstructed from these ice cores. To interpret the temperature record in the ice cores in the
Tibetan Plateau, detailed $\delta^{18} \mathrm{O}$ studies were undertaken through a network in the Tibetan Plateau. These studies have revealed a positive relationship between $\delta^{18} \mathrm{O}$ and air temperature (Yao and others, 1996; Yao, 1999). However, there was no continuous gas measurement for these ice cores. A few sporadic $\mathrm{CH}_{4}$ measurements were performed on the Dunde ice core, showing very high concentrations (in the range of a few ppmv) and scattering, which indicates that strong summer melting may produce additional methane (Xu and others, 1999). Recently, we have been engaged in recovering ice cores from very high altitudes, in order to reconstruct a reliable methane-concentration signal such that a reasonable comparison can be made between $\delta^{18} \mathrm{O}$ and methane concentration. The present paper discusses the first continuous measurement of $\delta^{18} \mathrm{O}$ and methane concentration from the Dasuopu ice core, recovered from the Himalaya.

\section{THE DASUOPU ICE-GORE ANALYSIS AND DATING}

The Dasuopu ice core was recovered from Dasuopu glacier $\left(28^{\circ} 23^{\prime} \mathrm{N}, 85^{\circ} 43^{\prime} \mathrm{E}\right)$, located on Xixabangma on the northern slope of the Himalaya. The length and area of the glacier are $10.5 \mathrm{~km}$ and $21.67 \mathrm{~km}^{2}$, respectively. The glacier terminates at about $5600 \mathrm{ma}$ a.s.l., and its snowline is at around $6000 \mathrm{~m}$ a.s.l. The col of the glacier is a large platform with an altitude of $>7000 \mathrm{~m}$ a.s.l. The platform is about $4 \mathrm{~km}$ long and $1 \mathrm{~km}$ wide. The annual glacial accumulation is about $1000 \mathrm{~mm} \mathrm{a}^{-1}$, allowing a high-resolution reconstruction of methane for recent times. The ice temperature at $10 \mathrm{~m}$ depth is $-16^{\circ} \mathrm{C}$ and it is still $-13^{\circ} \mathrm{C}$ at the bedrock. 


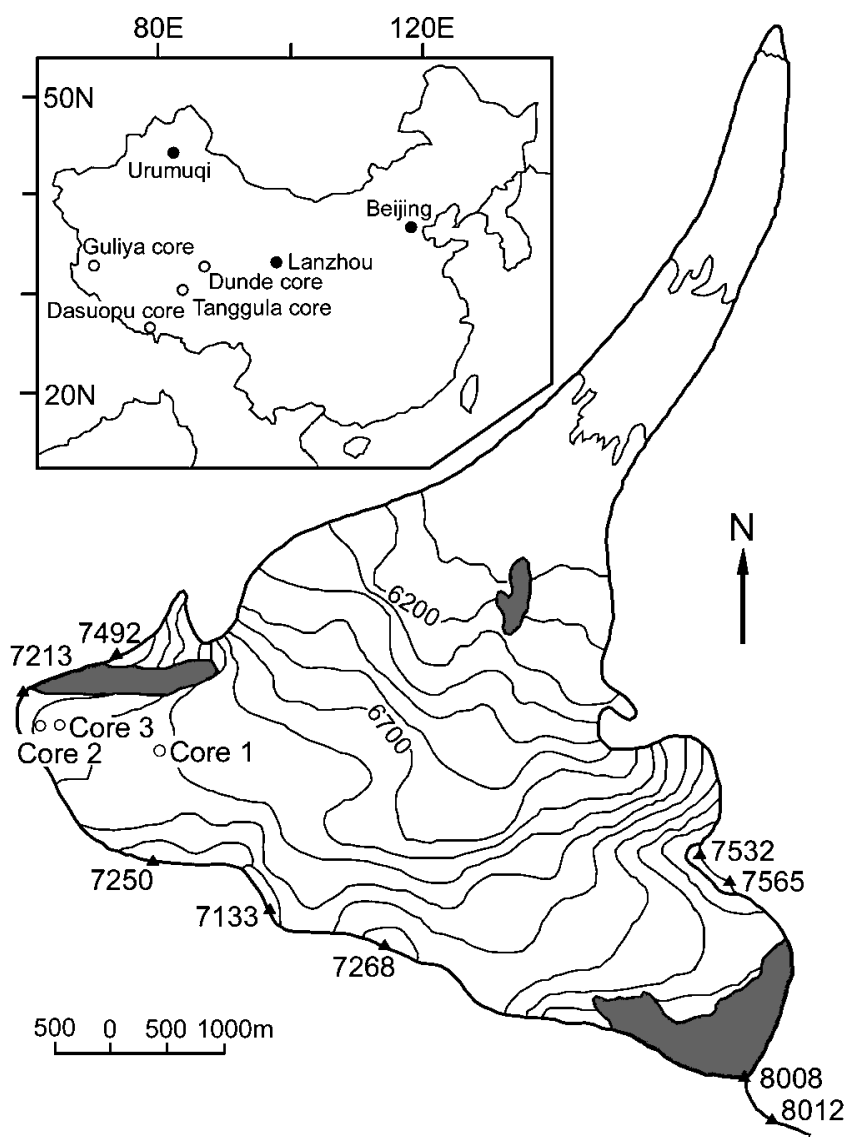

Fig. 1. The location of Dasuopu glacier and the ice-core sites.

Our field investigation indicates that there are thin melt layers in some parts of the ice core. The average melt-layer thickness is $4-4.5 \mathrm{~cm}$ and represents $<7 \%$ of the annuallayer thickness (Yao and others, 1999a). We therefore believe that the glacier should be suitable for ice-core methane reconstruction, provided that samples are taken at depths free of melt features. It should also be acknowledged that the methane measurements for some specific years with melt layers might not be representative of atmospheric methane concentration. Three cores were recovered in 1997 from Dasuopu glacier (see Fig. 1) in the dry-snow zone. The first core, $159.9 \mathrm{~m}$ long, was drilled at $7000 \mathrm{~m}$ a.s.l. down the flowline from the top of the col. The second core (core 2), $149.2 \mathrm{~m}$ long, was drilled on the col at $7200 \mathrm{~m}$ a.s.l. The third core, $167.7 \mathrm{~m}$ long, was also drilled on the col at $7200 \mathrm{~m}, 100 \mathrm{~m}$ away from the second core. The results from core 2 are presented here.

Methane measurements in ice cores are the only means to reconstruct the history of atmospheric $\mathrm{CH}_{4}$ mixing ratios from decades to 400000 years. Ice cores can provide additional quantitative constraints on the paleobudget of methane (e.g. the difference of mixing ratio between different sites). The interpolar difference (Greenland-Antarctica) has been quantified over most of the Holocene and part of the deglaciation and the last glaciation (Chappellaz and others, 1997). When investigating the potential of low- to mid-latitude ice cores regarding methane temporal changes and difference of mixing ratio from site to site, the major caveat is the lack of constraint on the $\mathrm{CH}_{4}$ mixing ratio in tropical regions. Recovered from an altitude of $7200 \mathrm{~m}$ a.s.l. (the highest-ever drilled site in the world), the Dasuopu ice core provides a unique opportunity not only to study monsoon precipitation, but also to obtain a subtropical-latitude methane reconstruction because of its high altitude. At this altitude, ice temperature is low, and summer melting on the glacial surface is limited, so the original methane concentration has a good chance of being preserved. A total of 12000 ice core samples were analyzed for $\delta^{18} \mathrm{O}$, and 221 samples were analyzed for methane concentration. $\delta^{18} \mathrm{O}$ was measured with a MAT-252 spectrometer at the Laboratory of Ice Core and Cold Regions Environment (LICGRE), Chinese Academy of Sciences.

The methane measurements were performed in two laboratories. At the LICGRE, we used a melt extraction method similar to the one originally developed at the Laboratoire de Glaciologie et Géophysique de l'Environnement (LGGE) in France, with some differences in the material used for the extraction line. An ice sample representing $25 \%$ of the core section and about $6 \mathrm{~cm}$ of length is cut for methane measurements. The outer surface of each sample is removed to eliminate any external contamination. Each sample weighs about $80 \mathrm{~g}$. It is put into a stainless-steel container, which is sealed with a tinfoil $(\mathrm{Sn})$ O-ring wire. The container is then placed into a $-70^{\circ} \mathrm{C}$ alcohol bath, and linked to the extraction line equipped with Whitey and Vici valves, for evacuation during about $30 \mathrm{~min}$ (dynamic pressure $\sim 5 \mathrm{~Pa}$ ).

The ice sample is then melted within about $5-7 \mathrm{~min}$ by immersion of the container in a $-60^{\circ} \mathrm{C}$ warm-water bath. A piece of bronze is then fitted to the base of the container and soaked in a $-70^{\circ} \mathrm{C}$ alcohol bath. The melted sample is thus slowly refrozen from the bottom, expelling close to $100 \%$ of the dissolved air. The procedure takes about 30-35 min. After refreezing, the temperature of the bath is slightly increased to $-60^{\circ} \mathrm{C}$. The extracted gases are then expanded in an extraction line. After $30 \mathrm{~s}$ of equilibration, the gases in the sample loop are injected by the helium carrier gas into a gas chromatograph (HP6890GG) equipped with a flame ionization detector. The extracted air is used for $3-4$ consecutive injections. The gases volume of each injection is determined from the pressure in the sample loop, measured with a capacitive pressure sensor. Calibration of the GC is performed with a standard gas containing 756 ppbv of $\mathrm{CH}_{4}$ in synthetic air (gravimetric scale, provided by China national standard mass center).

Blank tests were performed by adding the $756 \mathrm{ppbv}$ gas standard to artificial bubble-free ice. The contamination caused by the melting appears to be proportional to the melting time, but is $<15$ ppbv when the melting time is within $10 \mathrm{~min}$. The melting time of our ice-sample measurement is controlled within approximately $5-7 \mathrm{~min}$. We therefore estimate the contamination generated by the LICGRE technique at $15 \pm 8 \mathrm{ppbv}$, and each measured $\mathrm{CH}_{4}$ concentration was corrected by subtracting 15 ppbv. The scattering of methane concentrations for three or four injections is $\pm 40 \mathrm{ppbv}(2 \sigma)$. A total of $146 \mathrm{CH}_{4}$ measurements were performed using the technique described here.

Seventy-five $\mathrm{CH}_{4}$ measurements were performed at LGGE, using the same technique as described in Chappellaz and others (1997). The main differences with the LICGRE technique consist in a sample weight of about $50 \mathrm{~g}$, a glass container sealed with indium wire, a warmer alcohol bath $\left(-50^{\circ} \mathrm{C}\right)$, and an extraction line allowing simultaneous work on seven samples. The GC is calibrated with a standard containing $499 \mathrm{ppbv}$ of $\mathrm{CH}_{4}$ in air (LGGE scale). Blank tests indicate a contamination of $20 \pm 11 \mathrm{ppbv}$, and overall uncertainty is $\pm 37 \mathrm{ppbv}(2 \sigma)$ for Dasuopu. The large uncertainty compared with polar ice cores is due to the low air content of the ice at high altitude. The agreement between the LICGRE and LGGE $\mathrm{CH}_{4}$ datasets is excellent; this confirms the validity of the intercalibration performed between the two laboratories using a standard gas and the D47 ice core. 


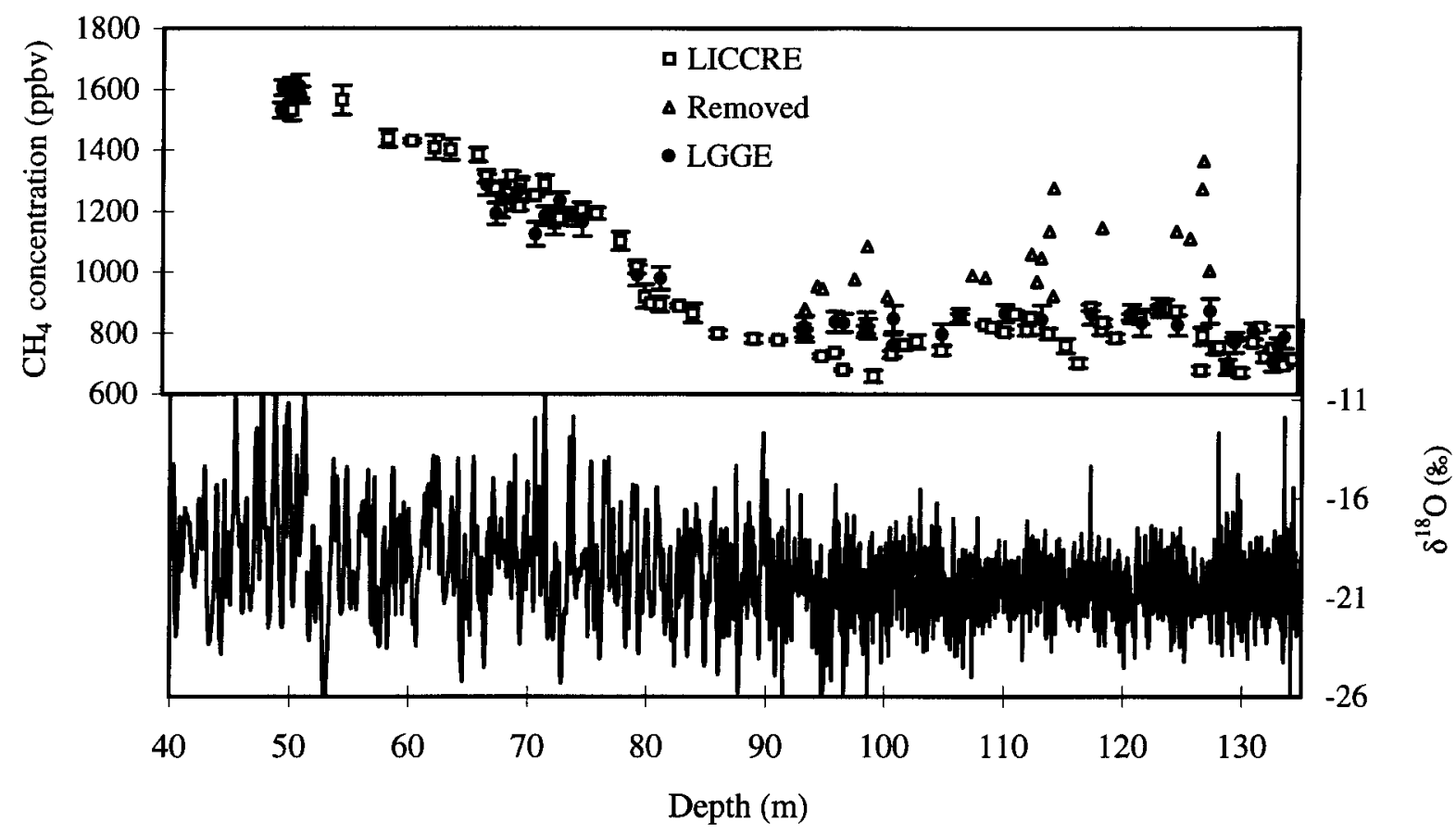

Fig. 2. $\delta^{18} \mathrm{O}$ and methane concentration records vs depth in the Dasuopu ice core.

Figure 2 presents $\delta^{18} \mathrm{O}$ and methane measurement vs depth for the upper $130 \mathrm{~m}$ which covers the last 1000 years. It is clear that $\delta^{18} \mathrm{O}$ becomes heavier as methane concentration increases, and that there is a phase difference between these two parameters, which is caused by their age difference. Age models are established separately for $\delta^{18} \mathrm{O}$ and methane in the present paper.

The high glacial accumulation, combined with pronounced and regular multi-parameter seasonal signals, makes it possible to date the core by using a comprehensive method of counting the seasonal variations in $\delta^{18} \mathrm{O}$, dust and chemical components, such as nitrate. The upper 550 years at $122 \mathrm{~m}$ depth have been annually dated using this comprehensive method. Below $122 \mathrm{~m}$, ice deformation made annual resolution of the record inaccurate. Therefore, from AD 550 to 1000 , the time-scale was determined by extrapolating the depth-age relation established for the upper $120 \mathrm{~m}$ and by assuming a constant annual accumulation rate (Bolzan, 1985; Reeh, 1988). The age error for the ice chronology is 5 years for the past 1000 years, <1year for the past 100 years and negligible for the past 40 years. $\beta$-activity peaks measured for these ice cores are in the 1962-63 range (Thompson and others, 2000).

The methane concentration presented here is based on the time series established for $\delta^{18} \mathrm{O}$ with consideration of iceage-gas-age difference. Understanding the ice-age-gas-age difference is very important for the reconstruction of atmospheric methane (Schwander and Stauffer, 1984; Sowers and others, 1997). Air trapped in air bubbles in the close-off region of glaciers has a different age from the surrounding ice, and one that is only slightly older than the overlying atmosphere at the time when firn-ice transition is completed, due to the time required for gases to diffuse through the firn column. For the Dasuopu core, bubble-volume and ice-density measurements indicate a mean close-off depth at $45 \mathrm{~m}$ corresponding to an age of 60 years. The $\mathrm{CH}_{4}$ diffusion time between the surface and $45 \mathrm{~m}$ is estimated at 10 years, based on permanent gas isotopes in bubbles, resulting in a mean delta age between the air and the ice of 50 years.

\section{THE DASUOPU ICE-CORE REGORDS}

Yao and others (2000) recently studied the precipitation record from core 2, while Thompson and others (2000) studied that from core 3 . The studies indicated a strong positive correlation between $\delta^{18} \mathrm{O}$ in the Dasuopu ice core and the air temperature in the Northern Hemisphere. They also indicated that $\delta^{18} \mathrm{O}$ has the same climatic significance in the Dasuopu ice core as in the Dunde and Guliya ice cores. However, $\delta^{18} \mathrm{O}$ in the Dasuopu ice core is not a direct indicator of atmospheric temperature over the glacier during snowfall; it is rather an indicator of sea surface temperature on a decadal time-scale. The $\delta^{18} \mathrm{O}$ signal in the Dasuopu ice core is a good temperature indicator, but the mechanism is different from that in the northern Tibetan Plateau.

On Dasuopu glacier, there are minor melt layers formed in summer. These layers can influence the methane record (melting reduces air content in ice and makes methane concentration higher than normal), resulting in abrupt jumps in the methane-concentration record. These jumps were excluded from the dataset for the present study. After correction of the dataset, the basic trend of atmospheric methane concentration in the past 1000 years is observed in the Dasuopu ice core. We therefore consider that the methane concentration in the Dasuopu ice core broadly represents the past atmospheric methane condition, although year-toyear concentration values may be inaccurate because of possible surface melting influence in some years.

It is interesting to compare the results from mid- to low latitudes with those from the polar regions. The most important feature of the Dasuopu ice-core record is that the methane concentration is higher than in the polar core records. Figure $3 \mathrm{a}$ shows the century-scale difference in methane concentration between the Dasuopu core, the Dome Summit South (DSS) and DE08 (Antarctica) cores (Etheridge and others, 1998) and the Greenland Icecore Project (GRIP) core (Blunier and others, 1993). For the pre-industrial period, Dasuopu has methane concentrations that are on average 120 ppbv higher than Greenland and 160 ppbv higher than 


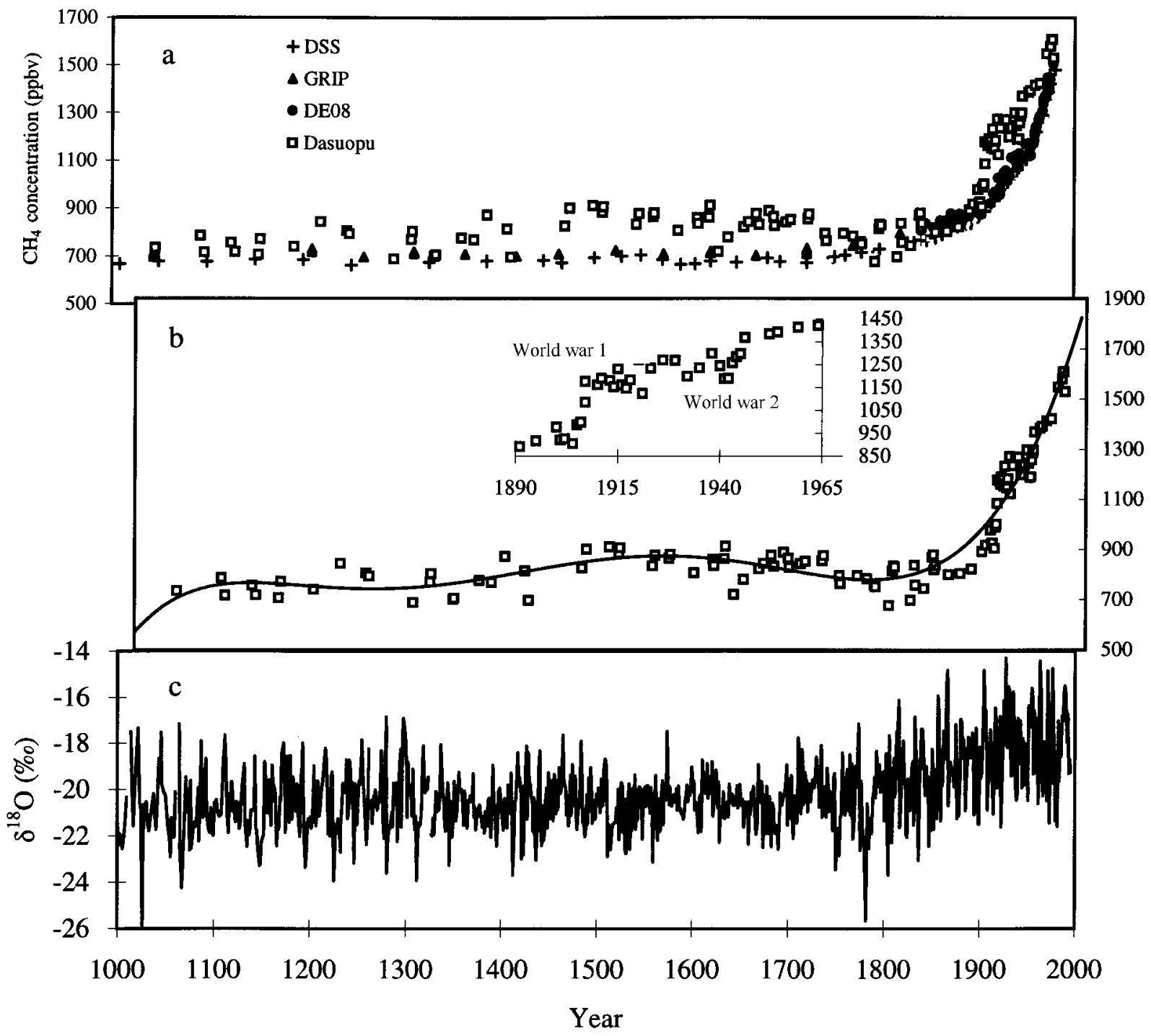

Fig. 3. ${ }^{18} \mathrm{O}$ and methane concentration fluctuations in the past 1000 years.

Antarctic values. We have no explanation for such high concentration differences, although the location is at the center of important $\mathrm{CH}_{4}$ sources. We also cannot exclude that a large part of the difference is due to an enrichment of methane in firn and ice due to the relatively high temperature.

Figure $3 \mathrm{~b}$ and $\mathrm{c}$ show the methane concentration and $\delta^{18} \mathrm{O}$ record in the past 1000 years from core 2. The Dasuopu record shows an obvious trend of $\delta^{18} \mathrm{O}$ and methane concentration increase in the past 1000 years. $\delta^{18} \mathrm{O}$ shows a dramatic increase after the 18th century, which is accompanied by an increase in methane concentration in the Dasuopu ice core. There has been a record increase in methane concentration since, more abrupt than the temperature increase, and we ascribe this to anthropogenic input. The unprecedented and continuous methane increase since the 18th century is similar to the observation from the polar regions (Sowers and others, 1997). The Dasuopu ice core therefore reveals an obvious positive correlation between methane concentration and temperature.

The Little Ice Age is well recorded in the Dasuopu ice core. From around AD 1500, there was a decrease in $\delta^{18} \mathrm{O}$ and a corresponding decrease in methane concentration. The methane-concentration decrease continued to the coldest period indicated by $\delta^{18} \mathrm{O}$. The last low- $\delta^{18} \mathrm{O}$ and lowmethane-concentration period appeared around AD 1750, the coldest period in the past 500 years. Many studies have shown a strong positive correlation between methane and $\delta^{18} \mathrm{O}$ on a glacial-interglacial time-scale (Raynaud and others, 1988; Thompson and others, 1989; Chappellaz and others, 1990; Petit and others, 1993, 1999; Thorpe and others, 1996). These studies conclude from the remarkable correlation between methane and temperature that methane contributes to the glacial-interglacial changes by amplifying the orbital forcing along with albedo and other possible changes (Raynaud and others, 1993). The amplifying effect of methane on climate has been quantitatively calculated (Raynaud and others, 1993). The Dasuopu ice core shows that there is a close positive relationship between methane and $\delta^{18} \mathrm{O}$ even on the very recent time-scale.

The high accumulation rate and the large number of measurements in the Dasuopu ice core reveal a significant period, covering World Wars I and II, when the $\mathrm{CH}_{4}$ mixing ratio over the Himalaya became stable or even decreased (see Fig. $3 \mathrm{~b}$ ). Such a temporal trend has been suggested in the DE08 ice core, but was less evident from the latest Antarctic dataset from DE08 and DSS (Etheridge and others, 1998). The distance of Antarctica from the main $\mathrm{CH}_{4}$ sources, combined with the relatively short duration of the stabilization event (20 years), may explain the difference in signature of this event in the Dasuopu and Antarctic ice cores. 


\section{GONGLUSIONS}

The Dasuopu ice core has provided a unique opportunity to study the relationship between $\delta^{18} \mathrm{O}$ and methane concentration at mid- to low latitudes, which demonstrated the potential to study the history of atmospheric methane concentration in the region.

The Dasuopu ice-core record shows a trend of climatic warming and methane-concentration increase in the past 1000 years. The Little Ice Age is well recorded in the Dasuopu ice core. The abrupt decrease in methane concentration in the past 500 years appeared around the 1750 s, which is the coldest period in the Little Ice Age. Subsequently, temperature and methane concentration dramatically increased. The methane-concentration increase is much more dramatic than the temperature increase, which we attribute to the anthropogenic impact. The observed decrease in methane concentration during World Wars I and II also indicates the anthropogenic impact, if further measurements prove that it is a true atmospheric signal.

The most important feature of the Dasuopu ice-core record is a higher methane concentration than in the polar ice-core records. We have no explanation for such high concentration differences, although the location is at the center of important $\mathrm{CH}_{4}$ sources. We also cannot exclude that much of the difference is due to an enrichment of methane in firn and ice due to the relatively high temperature. The minor melting features existing in the Dasuopu ice core resulted in inaccurate methane-concentration reconstruction for some years with very high temperature. It is therefore necessary to find new ice-core drilling sites that are higher than $7200 \mathrm{~m}$ in the Himalaya or at the same altitude but further north.

\section{ACKNOWLEDGEMENTS}

This work was supported by the Ministry of Science and Technology of China (grant No. G1998040807), the Chinese Academy of Sciences (grant No. KZCX2-301), the National Natural Science Foundation of China, and the U.S. National Science Foundation.

\section{REFERENGES}

Blunier, T. and 6 others. 1993. Atmospheric methane, record from a Greenland ice core over the last 1000 years. Geophys. Res. Lett., 20(20), 2219-2222.

Blunier, T., J. Chappellaz, J. Schwander, B. Stauffer and D. Raynaud. 1995. Variations in atmospheric methane concentration during the Holocene epoch. Nature, 374(6517), 46-49.

Bolzan, J. F. 1985. Ice flow at the Dome C ice divide based on a deep temperature profile. 7. Geophys. Res., 90(D5), 8111-8124.

Chappellaz, J., J. M. Barnola, D. Raynaud, Ye. S. Korotkevich and C. Lorius. 1990. Ice-core record of atmospheric methane over the past 160,000 years. Nature, 345(6271), 127-131.

Chappellaz, J. A., I.Y. Fung and A. M. Thompson. 1993a. The atmospheric $\mathrm{CH}_{4}$ increase since the Last Glacial Maximum. 1. Interaction with oxidants. Tellus, 45B (3), 242-257.

Chappellaz, J., T. Blunier, D. Raynaud, J. M. Barnola, J. Schwander and B. Stauffer. 1993b. Synchronous changes in atmospheric $\mathrm{CH}_{4}$ and Greenland climate between 40 and 8 kyr BP. Nature, 366(6454), 443-445.
Chappellaz, J. and 7 others. 1997. Changes in the atmospheric $\mathrm{CH}_{4}$ gradient between Greenland and Antarctica during the Holocene. 7. Geophys. Res., 102(D13), 15,987-15,997.

Etheridge, D. M., L. P. Steele, R. J. Francey and R. L. Langenfelds. 1998. Atmospheric methane between $1000 \mathrm{AD}$ and present: evidence of anthropogenic emissions and climatic variability. 7. Geophys. Res., 103(D13), 15,979-15,993.

Jones, P. D., T. J. Osborn and K. R. Briffa. 2001. The evolution of climate over the last millennium. Science, 292(5517), 662-667.

Petit, J.-R. and 18 others. 1999. Climate and atmospheric history of the past 420,000 years from the Vostok ice core, Antarctica. Nature, 399(6735), 429-436.

Rasmussen, R. A. and M. A. K. Khalil. 1984. Atmospheric methane in the recent and ancient atmospheres: concentrations, trends, and interhemispheric gradient. 7. Geophys. Res., 89(D7), 11,599-11,605.

Raynaud, D., J. Chappellaz, J.-M. Barnola, Ye. S. Korotkevich and C. Lorius. 1988. Climatic and $\mathrm{CH}_{4}$ cycle implications of glacial-interglacial $\mathrm{CH}_{4}$ change in the Vostok ice core. Nature, 333(6174), 655-657.

Raynaud, D., J. Jouzel, J. M. Barnola, J. Chappellaz, R. J. Delmas and C. Lorius. 1993. The ice record of greenhouse gases. Science, 259(5097), 926-934.

Reeh, N. 1988. A flow-line model for calculating the surface profile and the velocity, strain-rate, and stress fields in an ice sheet. F. Glaciol., 34(116), 46-54.

Schwander, J. and B. Stauffer. 1984. Age difference between polar ice and the air trapped in its bubbles. Nature, 311(5981), 43-47.

Sowers, T. and 10 others. 1997. An interlaboratory comparison of techniques for extracting and analyzing trapped gases in ice cores. 7. Geophys. Res., 102(C12), 26,527-26,538

Stauffer, B., E. Lochbrinner, H. Oeschger and J. Schwander. 1988. Methane concentration in the glacial atmosphere was only half that of the preindustrial Holocene. Nature, 332(6167), 812-815.

Thompson, L. G., E. Mosley-Thompson, J. F. Bolzan and B. R. Koci. 1985. A 1500-year record of tropical precipitation in ice cores from the Quelccaya ice cap, Peru. Science, 229(4717), 971-973.

Thompson, L. G. and 9 others. 1989. Holocene-Late Pleistocene climatic ice core records from Qinghai-Tibetan Plateau. Science, 246(4929), 474-477.

Thompson, L. G. and 7 others. 1995. Late glacial stage and Holocene tropical ice core records from Huascarán, Peru. Science, 269(5220), 46-50.

Thompson, L. G. and 9 others. 1997. Tropical climate instability: the last glacial cycle from a Qinghai-Tibetan ice core. Science, 276(5320), 1821-1825.

Thompson, L. G. and 11 others. 1998. A 25,000-year tropical climate history from Bolivian ice cores. Science, 282(5395), 1858-1864.

Thompson, L. G., T. Yao and E. Mosley-Thompson. 2000. A high-resolution millennial record of the south Asian monsoon from Himalayan ice cores. Science, 289(5486), 1916-1919.

Thorpe, R. B., K. S. Law, S. Bekki, J. A. Pyle and E. G. Nisbet. 1996. Is methane-driven deglaciation consistent with the ice core record? F. Geophys. Res., 101(D22), 28,627-28635.

Xu Baiqing, Yao Tandong, Tian Lide and J. Chappellaz. 1999. Variation of $\mathrm{CH}_{4}$ concentration recorded in Dunde ice core bubbles. Chin. Sci. Bull. 44(4), 383-384.

Yao Tandong. 1997. High resolution record of paleoclimate since the Little Ice Age from the Tibetan ice cores. Quat. Int., 37, 19-23.

Yao Tandong. 1999. High resolution climatic record from Tibetan ice cores. International Association of Hydrological Sciences Publication 256 (Symposium at Birmingham 1999-Interactions between the Cryosphere, Climate and Greenhouse Gases), 227-234.

Yao Tandong, L. G. Thompson, E. Mosley-Thompson, Yang Zhihong, Zhang Xinping and Lin Ping-Nan. 1996. Climatological significance of $\delta^{18} \mathrm{O}$ in north Tibetan ice cores. 7. Geophys. Res., 101 (D23), 29,531-29,538.

Yao Tandong, Pu Jianchen, Wang Ninglian and Tian Lide. 1999a. A new type of ice formation zone found in the Himalayas. Chin. Sci. Bull., 44(5), 469-473.

Yao Tandong, V. Masson, J. Jouzel, M. Stiévenard, W. Sun and K. Jiao. 1999b. Relationship between $\delta^{18} \mathrm{O}$ in precipitation and surface air temperature in the Ürümqi river basin, east Tianshan mountains, China. Geophys. Res. Lett., 26(23), 3473-3476.

Yao Tandong, Duan Keqin and Tian Lide. 2000. Glacial accumulation record in the Dasuopu ice core and Indian summer monsoon rainfall in the past 400 years. Science in China, 30 (6), 619-627. 